(c) American Dairy Science Association, 2005.

\title{
Quarter Health, Milking Interval, and Sampling Time During Milking Affect the Concentration of Milk Constituents
}

\author{
N. I. Nielsen, T. Larsen, M. Bjerring, and K. L. Ingvartsen \\ Department of Animal Health, Welfare and Nutrition, Danish Institute of Agricultural Sciences, \\ Research Centre Foulum, P.O. Box 50, 8830 Tjele, Denmark
}

\begin{abstract}
Eleven Danish Holstein cows were used to examine the effects of quarter health (healthy vs. unhealthy), milking interval (12 vs. $6 \mathrm{~h}$ ), and sampling time during milking on the concentration of 8 milk constituents [acetone, $\beta$-hydroxybutyrate (BHBA), N-acetyl- $\beta$-D-glucosaminidase (NAGase), somatic cell count (SCC), urea, fat, protein, and lactose]. The selection criterion was that each cow should have 2 or 3 healthy and 1 or 2 unhealthy quarters. Foremilk was collected before attaching the teat cups of the milking machinery, and thereafter, milk samples were collected automatically from each quarter every $45 \mathrm{~s}$ during milking. Compared with milk from healthy quarters, milk from unhealthy quarters had a higher concentration of BHBA, NAGase, SCC, and protein during the entire milking, whereas urea was higher in the last part of the milking process. Healthy quarters had a higher content of acetone and lactose during the whole milking, whereas fat was higher in the first part of the milking process. When the cows were milked at the 6 -h interval, all milk constituents except lactose and protein were higher during the whole (NAGase, SCC, and urea) or part of the milking (acetone, BHBA, and fat) compared with when cows were milked at the 12 -h interval. Lactose was higher in the first part of the milking at the 12-h compared with the 6-h interval, whereas protein was not affected by milking interval. $\beta$-Hydroxybutyrate, NAGase, SCC, and fat increased during the milking process, whereas acetone, urea, protein, and lactose decreased. Foremilk was remarkably different for all constituents, except acetone, and should not be used as a representative milk sample to achieve the true level of a milk constituent. If these milk constituents are to be used in an inline management system, these effects should be taken into account.
\end{abstract}

Received December 13, 2004

Accepted May 13, 2005.

Corresponding author: Nicolaj I. Nielsen; e-mail: Nicolaj.Nielsen@ agrsci.dk.
(Key words: milking interval, quarter health, milk fraction, in-line sampling)

Abbreviation key: CMT = California mastitis test.

\section{INTRODUCTION}

Dairy herd size has expanded rapidly in several countries in recent years. At the same time, automatic systems for feeding or milking have become more common. These changes have led to an increased number of cows being managed per person; and therefore, the interest in tools that can help the farmer with nutritional monitoring and early identification of diseases is growing. Measurements of different milk constituents have been suggested for assessing cow health and evaluating feed management systems (Hamann and Krömker, 1997; Mottram et al., 2002; Nielsen et al., 2005).

Milk constituents such as acetone (Andersson, 1984), BHBA (Horber et al., 1980; Nielsen et al., 2005), fat/ protein ratio (Heuer et al., 1999), and fat/lactose ratio (Steen et al., 1996) have been shown to indicate subclinical and clinical ketosis; and SCC and NAGase have been identified as indicators of subclinical and clinical mastitis (Pyörälä, 1988; Holdaway et al., 1996; Urech et al., 1999). In several countries, urea in milk is used as an indicator of the nutritional balance between protein and carbohydrate in a diet (Steen et al., 1996; Godden et al., 2000; Rajala-Schultz and Saville, 2003). Moreover, changes in milk fat and milk protein contents in relation to changes in feeding are of interest to the farmer, because the economic value of the milk depends on the content of fat and protein.

Using these milk constituents as the basis for an in-line health and feed management system requires knowledge about factors that could affect the concentration of milk constituents in relation to milk sampling. Generally, very little is known about how quarter health, milk interval, and milk fraction affect the concentration of acetone, BHBA, and urea; and these factors are of particular interest. More knowledge has been generated in relation to sampling factors for SCC, NAGase, fat, protein, and lactose, and it is known that milk fat content increases during milking (Lollivier et 
al., 2002; Vangroenweghe et al., 2002; Ontsouka et al., 2003). The content of protein and lactose has been reported to be lower in post-strippings compared with foremilk (Carlsson and Bergström, 1994; Holdaway et al., 1996; Godden et al., 2000; Vangroenweghe et al., 2002), although other studies found no difference for lactose and protein when comparing residual with cisternal milk (Wittkowski et al., 1979; Ontsouka et al., 2003; Bruckmaier et al., 2004).

Somatic cell counts and NAGase are highly elevated in milk from infected quarters (Pyörälä, 1988; Holdaway et al., 1996; Urech et al., 1999). Infected quarters have been shown to have a higher content of milk fat in some studies (Bruckmaier et al., 2004), whereas others have indicated a lower milk fat content in infected quarters (Laitinen, 1986; Holdaway et al., 1996). Generally, few studies have investigated the effect of quarter health on milk fat, protein, and lactose, and information is very limited with regard to how mastitic quarters affect other milk components such as acetone, BHBA, and urea.

Few studies have investigated the effect of milk interval on milk composition and mainly in relation to mastitis indicators. Thus, Marschke et al. (1987) and Kaartinen et al. (1990) found higher content of NAGase and SCC when cows were milked with an 8-h compared with a 16-h interval. However, Weiss et al. (2002) reported that milking interval had no influence on SCC. Milking interval is especially interesting in relation to dairy herds with robotic milking where large variations in the milking interval have been reported (Friggens and Rasmussen, 2001; Hogeveen et al., 2001).

Typically, changes in milk constituents during milking have been assessed by analyzing certain fractions (e.g., foremilk, midmilk, and post-strippings) and not by sampling during the whole milking process. Furthermore, to our knowledge, no studies have investigated the effects of quarter health, milk interval, and milk fraction simultaneously, and thereby, been able to examine possible interactions between these factors. The objective of this experiment was to study the effect of quarter health, milking interval, and sampling time during milking on the concentrations of acetone, BHBA, NAGase, SCC, urea, fat, protein, and lactose in milk.

\section{MATERIALS AND METHODS}

\section{Animals and Design}

Eleven Danish Holstein cows were used in the study of which 3 were in first, 5 in second, 2 in third, and 1 in fourth lactation. There were 5 cows in early lactation (range: 20 to $29 \mathrm{DIM}$ ) and 6 cows in late lactation (range: 193 to 393 DIM), the average daily milk yield being $27.3 \mathrm{~kg}$ (range: 15.6 to $38.3 \mathrm{~kg} / \mathrm{d}$ ). The cows were milked at 2 different intervals ( 6 and $12 \mathrm{~h}$ ) on the same day. Thus, in the morning, the cows were milked at a 12 -h interval (range: 12:03 to 13:11 h:min) and they were milked again $6 \mathrm{~h}$ (range: 5:50 to 6:05 h:min) later; that is, there were no repeated observations on milk interval across days, and all milk samplings were done in one day. The cows were selected within a research herd (Foulum, Denmark), the criterion being that each cow should have 2 or 3 healthy and 1 or 2 unhealthy quarters. The health of a quarter was determined based on a California mastitis test (CMT; Kruuse, Marslev, Denmark) in foremilk 7 and $1 \mathrm{~d}$ before the experimental milkings were carried out. Milk quarters with a CMT score of 1 or 2 on both days were considered healthy, whereas quarters with a CMT score of 3,4 , or 5 on both days were considered unhealthy. Although a few of the unhealthy milk quarters had visible changes in the milk, none of the quarters was under medical treatment during the trial. None of the cows was clinically ill or had decreased feed intake during the experimental milkings.

\section{Feeding}

The cows were housed in a tie stall and were fed a TMR ad libitum, which was available at all hours. The TMR consisted of barley whole crop silage (5.5\%), grass silage (31.4\%), barley straw (8.3\%), sugar beet molasses (11.3\%), rapeseed cake (16.2\%), barley (19.5\%), wheat $(6.8 \%)$, urea $(0.4 \%)$, and limestone $(0.6 \%)$ (\% of DM). As well as the TMR, each cow was fed $150 \mathrm{~g}$ of minerals (Type 1, Vitfoss, Gråsten, Denmark) daily. The TMR was fed twice a day in equal portions at 0900 and $1600 \mathrm{~h}$.

\section{Sampling of Milk}

The teats were cleaned with a firmly wrung cotton cloth and the first squirt of milk was discarded. Thereafter, the first milk fraction (the foremilk), which consisted of the first $24 \mathrm{~mL}$ of available milk, was collected manually before attaching the teat cups of the milking machine. The manual collection of foremilk was done as quickly as possible to avoid ejected milk in the last sampled quarter. The milk machinery was constructed to collect all milk from each quarter every $45 \mathrm{~s}$ during the milking of a cow, without having to remove the teat cups or stop the milking. The milk machinery consisted of a set of teat cups and pipelines from each quarter in which the milk was sucked up to a transportable device and distributed to quarter tubes. This transportable device, which was placed next to the cow during milking, had a switching device that made it possible to change between 2 sets of trays each containing 4 quarter tubes where all milk within $45 \mathrm{~s}$ was collected. Thus, 
every $45 \mathrm{~s}, 4$ clean quarter tubes were placed in the available tray, which was placed in the transportable device, ready for the next switch-over. The timing began when all teat cups were attached. The milking ended when all 4 quarters produced less than 500 g per $45 \mathrm{~s}$. All quarters, including the unhealthy quarters, produced enough milk in the last fractions so that it was possible to analyze all 8 milk constituents. After each milking, the milk machinery was emptied of milk residuals before milking the next cow. Every $45 \mathrm{~s}$, the milk collected from each quarter tube was weighed to calculate a composite concentration of NAGase and SCC for each fraction collected; that is, the amount of milk in each quarter tube collected every $45 \mathrm{~s}$ was dependent on milk flow in the quarter. After weighing, a representative milk sample from the given volume in each quarter-tube was transferred to 2 plastic tubes: 1) $17 \mathrm{~mL}$ of milk to a tube containing bronopol (Microtabs, D\&F Control Systems, Dublin, CA) for the analyses of acetone, SCC, fat, protein, and lactose; and 2) $7 \mathrm{~mL}$ of milk to a tube for the analyses of BHBA, NAGase, and urea. The plastic tubes were placed on ice immediately after sampling and stored at $4^{\circ} \mathrm{C}$ until analysis 1 to $3 \mathrm{~d}$ later.

\section{Laboratory Analyses}

Milk samples used for analysis of BHBA, NAGase, and urea were pipetted and diluted using a Biomek 2000 (Laboratory Automation Workstation, Beckman Coulter, Fullerton, CA). Reagents for BHBA and NAGase assays were added in the robotic system as well as in the fluorometer (Fluostar, BMG Labtechnologies, Germany). Analyses were performed in 96-well plates.

$\beta$-Hydroxybutyrate was analyzed using the enzymatic oxidation of the metabolite via BHBA-dehydrogenase (HBD-301, Toyobo Enzymes, Osaka, Japan), and a coupled reaction was determined by fluorometry (Larsen and Nielsen, 2005). The intraassay coefficient of variation for BHBA was 8.0 and $5.1 \%$ for low and high controls, respectively. The corresponding interassay coefficient of variation was 12.1 and $6.7 \%$ for low and high controls, respectively. The low $(0.08 \mathrm{mM})$ and high $(0.40 \mathrm{mM})$ controls had an accuracy (\% bias) of +9.4 and $-0.8 \%$, respectively.

Activity of NAGase was determined by an end-point fluorometric assay, according to Kitchen et al. (1978) and Schüttel (1999) with minor modifications to reagent composition. Samples were incubated for $18 \mathrm{~min}$ at $37^{\circ} \mathrm{C}$ with citrate-buffer, $\mathrm{pH} 4.6$, and substrate 4-methylumbelliferyl-N-acetyl- $\beta$-D-glucosaminide (M2133, Sigma, Copenhagen, Denmark). The hydrolysis was stopped by a Tritiplex-glycine buffer, $\mathrm{pH}$ 10.8; and emission of $460 \mathrm{~nm}$ monochromatic light was measured after excitation at $355 \mathrm{~nm}$. Standard curve ranges of 4-meth- ylumbelleferone were from 1 to $13.8 \mu \mathrm{mol} / \mathrm{min}$ per $\mathrm{L}$. The maximum absorbance of this method corresponded to a NAGase value of $13.8 \mu \mathrm{mol}$ of product/min per $\mathrm{L}$. The maximum level of NAGase was reached in 29 observations out of 670 . For these observations, a concentration of $13.8 \mu \mathrm{mol}$ of product/min per L was used. The intraassay coefficient of variation for NAGase was 8.3 and $5.5 \%$ for low and high controls, respectively. The corresponding interassay coefficient of variation was 12.4 and $6.2 \%$ for low and high controls, respectively. The low ( $1.7 \mu \mathrm{mol} / \mathrm{min}$ per L) and high $(7.3 \mu \mathrm{mol} /$ min per L) controls had an accuracy (\% bias) of +7.3 and $+4.4 \%$, respectively.

Urea was analyzed using flow injection analyses. Urease (URH-201, Toyobo Enzymes) was added to the diluted milk sample, and after the reaction, a strong alkali solution was added, and the developing ammonia was dialyzed through a membrane. Changes in $\mathrm{pH}$ in the passing aqueous phase were followed via a $\mathrm{pH}$ indicator by spectrophotometry. Application notes given by the manufacturer were followed (Foss Tecator $\mathrm{AB}$, Höganäs, Sweden). The intraassay coefficient of variation for urea was 3.4 and $1.6 \%$ for low and high controls, respectively. The corresponding interassay coefficient of variation was 5.1 and $1.4 \%$ for low and high controls, respectively. The low $(3.6 \mathrm{mM})$ and high (12.0 $\mathrm{m} M$ ) controls had an accuracy (\% bias) of -5.7 and $-1.0 \%$, respectively.

Acetone was analyzed using a flow injection method where the milk is dialyzed to separate acetone from other milk constituents (Foss Electric A/S). Subsequently, acetone is mixed with an indicator and detected by photometry. Analyses of SCC, fat, protein, and lactose were performed on a CombiFoss 4000 (Foss Electric A/S).

\section{Calculations and Statistical Analyses}

As the milkings of individual cows did not end at the same time, they were standardized across cows and intervals by the use of a relative scale (percentage of milking). That way, all quarters had a value at 0 and $100 \%$ of the milking, whereas samples taken in between were spread equidistantly between 0 and $100 \%$. A cow with 6 samplings for instance (excluding foremilk) would have values at $0,20,40,60,80$, and $100 \%$, whereas a cow with 9 samplings (excluding foremilk) would have values at $0,12.5,25,37.5,50,62.5,75,87.5$, and $100 \%$. The advantage of doing so was to avoid few cows with long milkings having a great influence on the concentrations of milk constituents at the end of the milking. Because the concentration of some milk constituents was remarkably different in the first fraction, that is, in the foremilk, it was decided to exclude 
the foremilk from the data analyses to achieve the best description of the development of each milk constituent during the milking with a second-degree polynomial. However, the simple mean concentration of each milk constituent in the foremilk is shown in the same figure as the least square means of each constituent during milking.

The concentrations of urea, protein, and lactose in fat-free milk were calculated based on the least square means for fat, urea, protein, and lactose. This was done according to the following equation: $[\mathrm{X} /(100-$ fat $)] \times$ $100 \%$, where $\mathrm{X}$ is either the concentration of urea, protein, or lactose, and fat is the fat percentage at a given time during milking.

Quantitative effects of quarter health, milking inter$\mathrm{val}$, and sampling time during milking on milk constituents were calculated as relative values, that is, differences in percentages based on the least square means. For example, the relative effect of quarter health was calculated within intervals (6 or $12 \mathrm{~h}$ ) at the time in milking where the difference between healthy and unhealthy quarters was largest, that is, as a simple difference in percentage between 2 concentrations.

The concentration of NAGase or SCC in composite milk was calculated based on milk weights recorded every $45 \mathrm{~s}$ during the milkings and the concentrations of NAGase or SCC in milk samples from individual quarters. Thus, the concentrations of NAGase or SCC in composite milk were calculated as the total amount of NAGase or SCC in all 4 quarters divided by the total milk production produced within every $45 \mathrm{~s}$. These calculated concentrations of NAGase and SCC in composite milk were used in a regression analysis where the model included milking interval, a linear and quadratic term of percentage of milking, and interaction terms.

The concentration of all milk constituents was calculated in foremilk and milk from the rest of the milking (rest milk) within quarter health and milk interval. The concentration of each milk constituent in rest milk was calculated as a composite concentration according to milk weight and concentration from each collection during milking (except foremilk). For example, the concentration of urea in rest milk in healthy quarters was calculated as the total amount of urea divided by the total milk production from all fractions collected in healthy quarters within cow and milking interval.

Data were analyzed using the MIXED procedure of SAS (SAS Institute, 1999). The model used to analyze effects of milking interval, quarter health, and the development in the concentration of milk constituents during milking was as follows:

$$
\begin{aligned}
\mathrm{Y}_{\mathrm{ijlm}}= & \mu+\alpha_{\mathrm{i}}+\delta_{\mathrm{j}}+(\alpha \delta)_{\mathrm{ij}}+\beta_{1 \mathrm{ij}} \mathrm{X}_{\mathrm{ij}}+\beta_{2 \mathrm{ij}} \mathrm{X}_{\mathrm{ij}}^{2} \\
& +\mathrm{A}_{\mathrm{l}}+\mathrm{B}_{\mathrm{m}}(\mathrm{A})_{1}+\mathrm{A}_{\mathrm{l}}(\alpha)_{\mathrm{i}}+\varepsilon_{\mathrm{ijl}}
\end{aligned}
$$

where $\mathrm{Y}_{\mathrm{ijlm}}=$ dependent variable; $\mu=$ overall mean; $\alpha_{\mathrm{i}}=$ fixed effect of milking interval i $\{\mathrm{i}=6 \mathrm{~h}, 12 \mathrm{~h}\} ; \delta_{\mathrm{j}}=$ fixed effect of quarter health $\mathrm{j}\{\mathrm{j}=$ healthy, unhealthy $\} ;(\alpha \delta)_{\mathrm{ij}}=$ interaction between milking interval $\mathrm{i}$ and quarter health $\mathrm{j} ; \beta_{1} \mathrm{X}_{\mathrm{ij}}=$ linear regression coefficient within milking interval $\mathrm{i}$ and quarter health $\mathrm{j}, \mathrm{X}$ is the percentage of milking; $\beta_{2} \mathrm{X}_{\mathrm{ij}}^{2}=$ regression coefficient within milking interval $\mathrm{i}$ and quarter health $\mathrm{j}, \mathrm{X}^{2}$ is the quadratic value of percentage of milking; $A_{1}=$ random effect of cow $1, \mathrm{~A}_{1} \sim \mathrm{N}\left(0, \sigma_{\mathrm{Al}}^{2}\right) ; \mathrm{B}_{\mathrm{m}}(\mathrm{A})_{1}=$ random effect of quarter $\mathrm{m}$ within cow $\mathrm{l}, \mathrm{B}_{\mathrm{m}}(\mathrm{A})_{1} \sim \mathrm{N}\left(0, \sigma_{\mathrm{B}}^{2}\right) ; \mathrm{A}_{\mathrm{l}}(\alpha)_{\mathrm{i}}=$ random effect of cow 1 within milking interval i, $\mathrm{A}_{\mathrm{l}}(\alpha)_{\mathrm{i}} \sim \mathrm{N}\left(0, \sigma_{\mathrm{Al}}^{2}\right)$; and $\varepsilon_{\mathrm{ijlm}}=$ residual error, $\varepsilon_{\mathrm{ijlm}} \sim \mathrm{N}\left(0, \sigma_{\varepsilon}^{2}\right)$.

The final model for each milk constituent was determined by backward elimination of nonsignificant $(P>$ $0.10)$ effects. The model included random effects accounting for variances between cows, between cows within milking interval, and between quarters within cow. The repeated samples on quarters within cow and interval was accounted for by choosing the covariance structure yielding the best fit, assessed by Akaike's information criterion. Least squares means were compared using the PDIFF option of the LSMEANS statement of the MIXED procedure. Bartlett's test was used to test for homogeneity of variance. Acetone, BHBA, NAGase, and SCC were $\log _{10}$-transformed to obtain a normal distribution of residuals. Unless otherwise stated, least square means and standard errors of the mean are reported.

\section{RESULTS}

\section{Level of NAGase and SCC in Healthy and Unhealthy Quarters}

The concentrations of NAGase and SCC in healthy and unhealthy quarters in relation to milking interval are presented in Table 1 . Unhealthy quarters clearly had higher levels of NAGase and SCC than healthy quarters in both milking intervals, although a few quarters overlapped between groups (see ranges in Table 1).

\section{Effects of Quarter Health and Milking Interval on Milk Constituents During Milking}

When the cows were milked at a 12-h interval, there were, on average, 9.0 samplings (range: 6 to 10) including foremilk from each quarter during a milking; on average, these milkings lasted $6 \min 45 \mathrm{~s}$. When the cows were milked at a 6 -h interval, there were $7.2 \mathrm{sam}$ plings (range: 5 to 9) including foremilk; on average, these milkings lasted 5 min $34 \mathrm{~s}$. Results on quarter health and milking interval and the development in the concentration of each milk constituent during milk- 
Table 1. Comparison of NAGase and SCC in healthy and unhealthy quarters in relation to milking interval (6 or $12 \mathrm{~h})$.

\begin{tabular}{|c|c|c|c|c|c|c|}
\hline \multirow{2}{*}{$\begin{array}{l}\text { Quarter } \\
\text { health }^{1}\end{array}$} & \multirow{2}{*}{$\begin{array}{l}\text { Milking } \\
\text { interval, h }\end{array}$} & \multirow[b]{2}{*}{$\mathrm{n}$} & \multicolumn{2}{|c|}{ NAGase ( $\mu \mathrm{mol}$ of product/min per L) } & \multicolumn{2}{|c|}{$\operatorname{SCC}(\times 1000 / \mathrm{mL})$} \\
\hline & & & Mean $\pm \mathrm{SE}$ & Range $^{2}$ & Mean $\pm \mathrm{SE}$ & Range $^{3}$ \\
\hline Healthy & 6 & 214 & $2.48 \pm 0.18$ & $0.99-5.21$ & $270 \pm 48$ & 11-997 \\
\hline Healthy & 12 & 266 & $2.02 \pm 0.14$ & $1.02-4.31$ & $151 \pm 21$ & $15-344$ \\
\hline Unhealthy & 6 & 93 & $7.92 \pm 0.57$ & $4.04-10.5$ & $4383 \pm 894$ & $559-10,275$ \\
\hline Unhealthy & 12 & 113 & $6.31 \pm 0.64$ & $2.76-10.2$ & $2568 \pm 641$ & $425-7896$ \\
\hline
\end{tabular}

\footnotetext{
${ }^{1}$ Each cow had 2 or 3 healthy quarters and 1 or 2 unhealthy quarters determined by CMT score where a score of 1 or 2 was regarded as healthy and a score of 3,4 , or 5 as unhealthy.

${ }^{2}$ Values are means of observations within a quarter of a cow $(n=5$ to 10$)$.
}

ing are described below and presented in Figure 1. Quantitative effects of quarter health, milking interval, and sampling time during milking on milk constituents were assessed as relative values and are presented in Table 2. To evaluate foremilk as a representative medium, a comparison of concentrations in foremilk and composite milk from the rest of the milking within quarter health and milking interval is given in Table 3.

Acetone. The concentration of acetone was lower $(P$ $<0.05$ ) in unhealthy than in healthy quarters during the whole milking process. The difference between healthy $(-0.54 \pm 0.10)$ and unhealthy $(-0.56 \pm 0.10)$ quarters corresponded to a relatively small geometric value of $0.013 \mathrm{~m} M$. Generally, acetone was also affected by milking interval $(P<0.05)$, being higher when the cows were milked at a 6 -h $(-0.53 \pm 0.10)$ compared with a 12 -h interval $(-0.57 \pm 0.10)$. The effect of interval corresponded to a geometric value of $0.025 \mathrm{mM}$. There was an interaction between interval and the linear and quadratic term of percentage of milking reflecting that when cows were milked at a 6 -h interval, the concentration of acetone was higher in the beginning and at the end of the milking than for the 12-h interval, whereas there was no significant difference in the middle of the milking. Acetone decreased during the milking when the cows were milked at a 6 -h interval, whereas there was a curve linear development for the 12-h interval resulting in an acetone peak in the middle of the milking process. Assessed on a relative scale, the acetone concentration differed by a maximum of $4 \%$ between healthy and unhealthy quarters within the milking process at the 6 -h interval and by a maximum of $7 \%$ at the 12-h interval (Table 2). Table 2 shows that the concentration of acetone was less sensitive to quarter health (4 to $7 \%$ ) than milking interval (15 to $19 \%$ ).

$\boldsymbol{B H B A}$. Unlike acetone, the concentration of BHBA was higher $(P<0.001)$ in unhealthy $(-0.89 \pm 0.06)$ than in healthy $(-1.05 \pm 0.06)$ quarters during the milking process, corresponding to a geometric difference of 0.04 $\mathrm{m} M$. Like acetone, the level of BHBA was higher when the cows were milked at a 6 -h $(-0.94 \pm 0.06)$ compared with a 12 -h interval $(-1.00 \pm 0.06)$, but the difference in BHBA between intervals was only significant in the first half of the milking process (interval $\times$ linear term of percentage of milking interaction, $P<0.001$ ). The concentration of BHBA increased during the milking, especially when the cows were milked at a 12 -h interval. Assessed on a relative scale, BHBA was much more affected by quarter health, milking interval, and sampling time during milking than acetone (Table 2).

NAGase. The concentration of NAGase was higher $(P<0.001)$ in unhealthy $(0.77 \pm 0.05)$ than in healthy $(0.28 \pm 0.04)$ quarters during the entire milking process. However, the difference in NAGase between healthy and unhealthy quarters was larger at the end of the milking than in the beginning (quarter health $\times$ linear term of percentage of milking interaction, $P<0.01$ ). There was a tendency to a larger difference in NAGase between intervals when quarters were unhealthy (quarter health $\times$ interval interaction, $P=0.08$ ). The content of NAGase was higher $(P<0.01)$ when the cows were milked at a 6 -h $(0.56 \pm 0.04)$ compared with a 12 -h interval $(0.50 \pm 0.04)$. However, an interaction between interval and the linear term of percentage of milking $(P<0.01)$ reflected that toward the end of the milking process, there was no longer a significant difference in NAGase between the 2 intervals. Concentration of NAGase showed a constant level in the beginning of the milking and then increased during the rest of the milking, especially in unhealthy quarters.

SCC. Like NAGase, the concentration of SCC was higher $(P<0.001)$ in unhealthy $(6.35 \pm 0.13)$ than in healthy $(4.98 \pm 0.11)$ quarters during the milking process. However, the difference in SCC between healthy and unhealthy quarters was greater in the middle of the milking than in the beginning and the end of the milking (quarter health $\times$ linear and quadratic term of percentage of milking interaction, $P<0.05)$. Generally, the SCC was higher $(P<0.01)$ when cows were milked at a 6 -h $(5.76 \pm 0.10)$ compared with a 12 -h interval $(5.56 \pm 0.10)$. However, an interaction between interval and the quadratic term of percentage of milking $(P<$ 

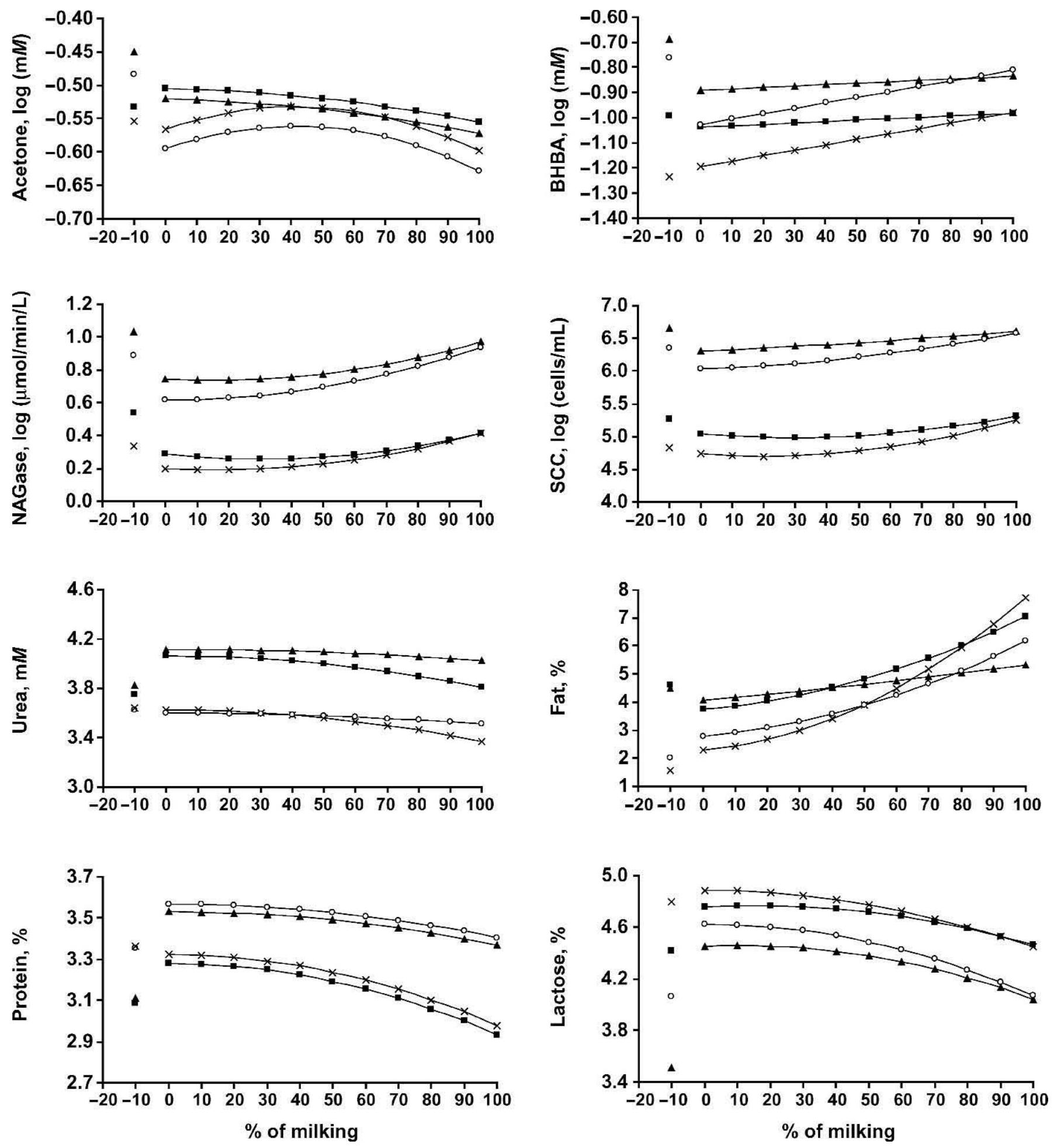

Figure 1. Concentrations (least square means) of milk constituents during milking (\% of milking) depending on quarter health (healthy

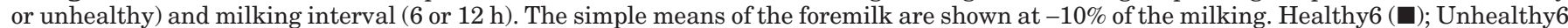
$(\mathbf{\Lambda})$; Healthy12 (×); Unhealthy12 $(\bigcirc)$. For standard errors, see results. 
Table 2. Quantitative effects of quarter health, milking interval, and sampling time during milking on milk constituents calculated as relative values based on least square means presented in Figure 1.

\begin{tabular}{|c|c|c|c|c|c|c|c|c|}
\hline \multirow[b]{2}{*}{ Milk constituent ${ }^{4}$} & \multicolumn{2}{|c|}{ Effect of health ${ }^{1}(\%)$} & \multicolumn{2}{|c|}{ Effect of interval ${ }^{2}(\%)$} & \multicolumn{4}{|c|}{ Effect of sampling time during milking ${ }^{3}(\%)$} \\
\hline & $6 \mathrm{~h}$ & $12 \mathrm{~h}$ & Healthy & Unhealthy & Healthy 6 & Healthy12 & Unhealthy6 & Unhealthy 12 \\
\hline Acetone & 4 & 7 & 15 & 19 & 12 & 17 & 12 & 17 \\
\hline NAGase & 263 & 231 & 22 & 34 & 44 & 68 & 72 & 109 \\
\hline $\mathrm{SCC}$ & 2364 & 2466 & 98 & 91 & 113 & 261 & 100 & 250 \\
\hline Urea & 6 & 4 & 13 & 15 & 7 & 8 & 2 & 3 \\
\hline Fat & 32 & 25 & 64 & 46 & 89 & 239 & 31 & 121 \\
\hline
\end{tabular}

${ }^{1}$ The relative effect of quarter health was calculated as the difference in percentage between the concentrations in healthy and unhealthy quarters at the time in milking where the difference was largest. This was done within intervals $(6$ or $12 \mathrm{~h})$.

${ }^{2}$ The relative effect of milking interval was calculated as the difference in percentage between the concentrations at 6 and 12 -h intervals at the time in milking where the difference was largest. This was done within quarter health (healthy or unhealthy).

${ }^{3}$ The relative effect of sampling time was calculated as the difference in percentage between the lowest and the highest concentration within the combinations of quarter health and interval (Healthy6, Healthy12, Unhealthy6, or Unhealthy12).

${ }^{4}$ For the $\log _{10}$-transformed constituents (acetone, BHBA, NAGase, and SCC), geometric values were used for the calculations of relative values.

0.01) reflected that toward the end of the milking process, there was no longer a significant difference in SCC between the 2 intervals. Unhealthy quarters showed a steady rise in SCC during milking, whereas the SCC in healthy quarters was nearly constant in the beginning of the milking and then increased during the rest of the milking. The quantitative effects of quarter health, milking interval, and sampling time during milking were large for SCC, also when compared with NAGase (Table 2).
Urea. Generally, there was no difference in urea between unhealthy $(3.82 \pm 0.16)$ and healthy $(3.75 \pm 0.16)$ quarters, but at the end of the milking process, there was a significantly higher urea content in unhealthy compared with healthy quarters (quarter health $\times$ quadratic term of percentage of milking interaction, $P<$ 0.05). However, these differences were quantitatively limited (Table 2). Urea was also affected by milking interval $(P<0.05)$, resulting in a higher level when the cows were milked at a 6 -h $(4.03 \pm 0.18)$ compared with

Table 3. Comparison of the concentration of milk constituents in foremilk and milk from the rest of the milking ${ }^{1}$ (least square means $\pm \mathrm{SE}$ )

\begin{tabular}{|c|c|c|c|c|c|}
\hline \multirow[b]{2}{*}{ Milk constituent ${ }^{2}$} & \multirow[b]{2}{*}{ Milk fraction } & \multicolumn{2}{|c|}{ Healthy quarters } & \multicolumn{2}{|c|}{ Unhealthy quarters } \\
\hline & & 6-h interval & 12-h interval & 6-h interval & 12-h interval \\
\hline \multirow[t]{2}{*}{ Acetone } & Foremilk & $-0.51 \pm 0.10$ & $-0.53 \pm 0.11$ & $-0.52 \pm 0.10$ & $-0.54 \pm 0.11$ \\
\hline & Rest milk & $-0.51 \pm 0.10$ & $-0.55 \pm 0.11$ & $-0.53 \pm 0.10$ & $-0.57 \pm 0.11$ \\
\hline \multirow[t]{2}{*}{ BHBA } & Foremilk & $-0.98 \pm 0.05$ & $-1.13 \pm 0.07 *$ & $-0.68 \pm 0.10^{*}$ & $-0.79 \pm 0.14$ \\
\hline & Rest milk & $-1.03 \pm 0.05$ & $-1.03 \pm 0.07$ & $-0.88 \pm 0.10$ & $-0.91 \pm 0.14$ \\
\hline \multirow[t]{2}{*}{ NAGase } & Foremilk & $0.56 \pm 0.06^{*}$ & $0.36 \pm 0.05^{*}$ & $1.04 \pm 0.05^{*}$ & $0.88 \pm 0.07^{*}$ \\
\hline & Rest milk & $0.28 \pm 0.06$ & $0.25 \pm 0.05$ & $0.77 \pm 0.05$ & $0.72 \pm 0.07$ \\
\hline \multirow[t]{2}{*}{$\mathrm{SCC}$} & Foremilk & $5.40 \pm 0.15^{*}$ & $4.95 \pm 0.12$ & $6.70 \pm 0.12^{*}$ & $6.45 \pm 0.15^{*}$ \\
\hline & Rest milk & $5.15 \pm 0.15$ & $5.01 \pm 0.12$ & $6.40 \pm 0.40$ & $6.29 \pm 0.15$ \\
\hline \multirow[t]{2}{*}{ Urea } & Foremilk & $3.72 \pm 0.18^{*}$ & $3.65 \pm 0.22^{*}$ & $3.91 \pm 0.15^{*}$ & $3.61 \pm 0.22$ \\
\hline & Rest milk & $3.95 \pm 0.18$ & $3.56 \pm 0.22$ & $4.13 \pm 0.15$ & $3.57 \pm 0.22$ \\
\hline \multirow{2}{*}{ Fat } & Foremilk & $4.73 \pm 0.36$ & $1.58 \pm 0.19^{*}$ & $4.41 \pm 0.46$ & $1.94 \pm 0.19^{*}$ \\
\hline & Rest milk & $4.65 \pm 0.36$ & $3.91 \pm 0.19$ & $4.46 \pm 0.44$ & $3.99 \pm 0.18$ \\
\hline \multirow[t]{2}{*}{ Protein } & Foremilk & $3.07 \pm 0.13^{*}$ & $3.35 \pm 0.12^{*}$ & $3.27 \pm 0.18^{*}$ & $3.39 \pm 0.15$ \\
\hline & Rest milk & $3.21 \pm 0.13$ & $3.24 \pm 0.12$ & $3.54 \pm 0.18$ & $3.54 \pm 0.15$ \\
\hline \multirow[t]{2}{*}{ Lactose } & Foremilk & $4.39 \pm 0.08^{*}$ & $4.77 \pm 0.08$ & $3.52 \pm 0.20^{*}$ & $4.09 \pm 0.21$ \\
\hline & Rest milk & $4.71 \pm 0.08$ & $4.76 \pm 0.08$ & $4.44 \pm 0.19$ & $4.49 \pm 0.21$ \\
\hline
\end{tabular}

${ }^{1}$ The concentration in milk from the rest of the milking (rest milk) was calculated as a composite concentration according to milk weight and concentration from each collection during milking within quarter health and milking interval.

${ }^{2}$ Acetone, BHBA, NAGase, and SCC were $\log _{10}$-transformed.

*Significant difference $(P<0.05)$ between foremilk and rest milk within quarter health and milking interval. 
a 12-h interval ( $3.55 \pm 0.18)$. There was a higher content of urea in unhealthy than in healthy quarters when the cows were milked at a 6 -h interval, but this difference was not evident when the cows were milked at a 12-h interval (quarter health $\times$ interval interaction, $P$ $<0.05)$. Healthy quarters had a decreasing content of urea toward the end of the milking, whereas urea in unhealthy quarters did not change significantly with milking time. Furthermore, because urea, protein, and lactose are mainly soluble in hydrophilic phases, the concentrations of these milk constituents were calculated in fat-free milk based on the least square means presented in Figure 1. This was done to evaluate if the increase in fat during milking could explain the decrease in urea, protein, and lactose during milking (Figure 2). Comparing urea in Figures 1 and 2, it becomes evident that the increase in fat as the milking progresses may explain some of the decrease in urea, but not all.

Fat. The milk fat content was lower in unhealthy $(4.40 \pm 0.33)$ than in healthy $(4.72 \pm 0.31)$ quarters, but the difference was only significant during the last half of the milking (quarter health $\times$ quadratic term of percentage of milking interaction, $P<0.001$ ). The milk fat content was also affected by milking interval $(P<0.01)$, being higher when the cows were milked at a $6-\mathrm{h}(4.86$ $\pm 0.35)$ compared with a 12 -h interval $(4.25 \pm 0.35)$. However, an interaction between interval and the quadratic term of percentage of milking $(P<0.001)$ reflected that when the cows were milked at a 6 -h interval, milk fat was only significantly higher compared with a 12 $\mathrm{h}$ interval during the first half of the milking. Fat increased during milking $(P<0.001)$, but when cows were milked at a 12-h interval, the milk fat content started out relatively low and then increased more dramatically than was seen for the 6 -h interval. Generally, the quantitative effects of quarter health, milking interval, and sampling time during milking were pronounced for fat (Table 2).

Protein. The milk protein content was higher $(P<$ $0.01)$ in unhealthy $(3.49 \pm 0.14)$ than in healthy (3.18 \pm 0.13 ) quarters during the whole milking. However, the difference in protein content between healthy and unhealthy quarters was larger at the end of the milking than in the beginning (quarter health $\times$ quadratic term of percentage of milking interaction, $P<0.001$ ). Milk protein content was similar for the 6 -h $(3.31 \pm 0.13)$ and 12 -h $(3.35 \pm 0.13)$ milking intervals. Assessed on a relative scale, protein was much more affected by quarter health than milking interval (Table 2). Protein content was constant at the beginning of the milking but then dropped $(P<0.001)$ toward the end of the milking. Figure 2 shows that protein content calculated in fat-free milk decreased toward the end of the milking,
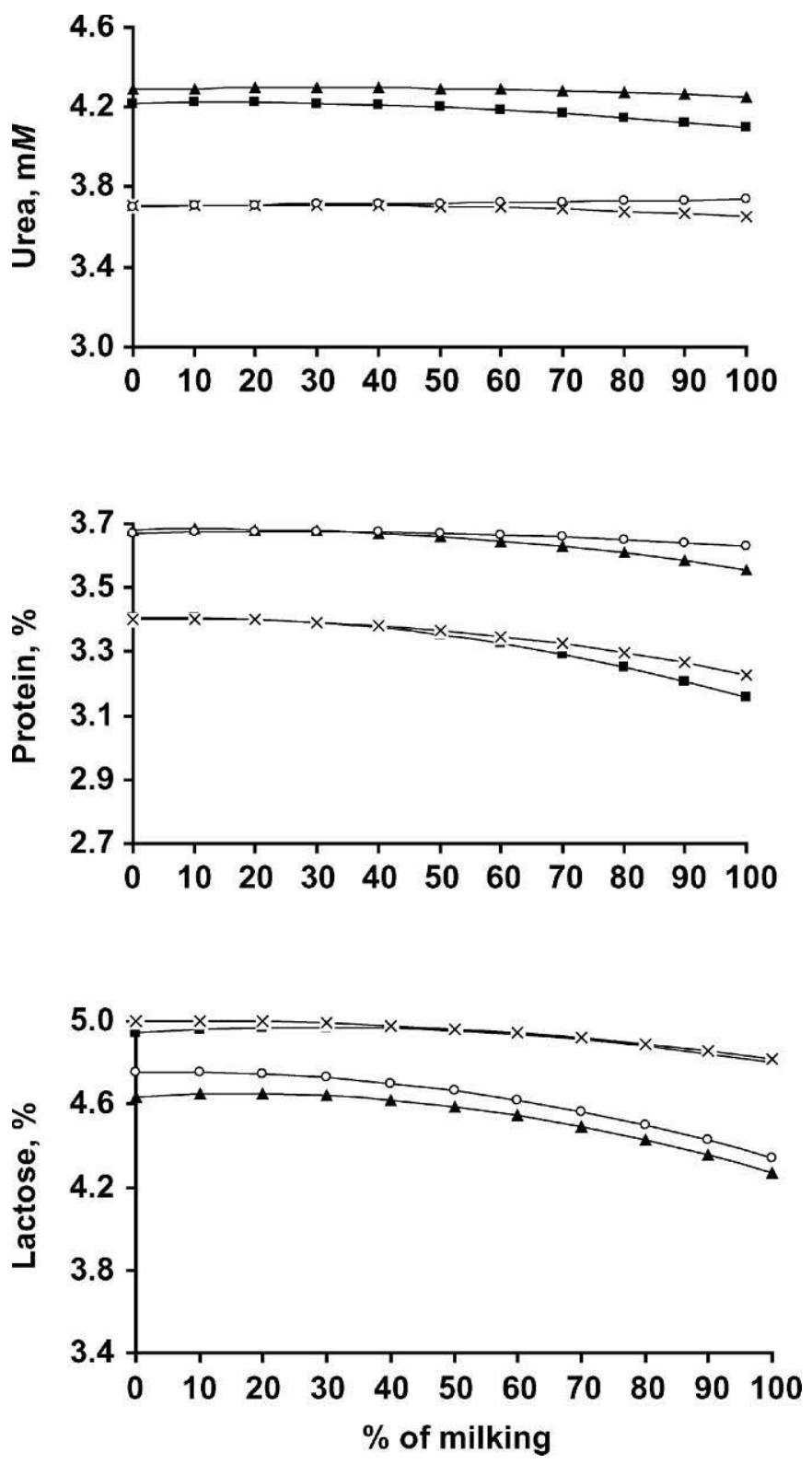

Figure 2. Concentrations of urea, protein, and lactose in fat-free milk during milking (\% of milking) depending on quarter health (healthy or unhealthy) and milking interval (6 or $12 \mathrm{~h}$ ). Concentrations in fat-free milk were calculated based on the least square means for fat, urea, protein, and lactose presented in Figure 1. Healthy6

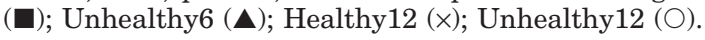

although it was not as pronounced as in whole milk (Figure 1). Therefore, the rise in fat content was not solely responsible for the drop in protein as the milking progressed.

Lactose. The milk lactose content was lower $(P<$ $0.001)$ in unhealthy $(4.37 \pm 0.06)$ than in healthy $(4.70$ $\pm 0.05)$ quarters during the entire milking. However, the difference in lactose content between healthy and 
unhealthy quarters was larger at the end of the milking than in the beginning (quarter health $\times$ quadratic term of percentage of milking interaction, $P<0.001$ ). The milk lactose content was generally lower $(P<0.01)$ when the cows were milked at a 6 -h $(4.49 \pm 0.05)$ compared with a 12 -h interval $(4.57 \pm 0.05)$. An interaction between interval and the linear term of percentage of milking $(P<0.001)$ reflected that toward the end of the milking there was no longer a significant difference in lactose between milking intervals. Lactose was constant at the beginning of the milking but then decreased $(P<0.001)$ toward the end of the milking. Generally, the quantitative effects of quarter health, milking interval, and sampling time during milking were $\leq 10 \%$ (Table 2 ). As for protein, the increase in fat as the milking progressed could only partly explain the decrease in lactose toward the end of the milking (Figure 2).

\section{Composite or Quarter Samples for Identifying Unhealthy Quarters}

The difference between measuring NAGase or SCC in composite milk or milk from individual healthy/unhealthy quarters is shown in Figures 3 and 4. The concentration of NAGase or SCC in composite milk was calculated based on milk weights recorded every $45 \mathrm{~s}$ during milking and concentrations of NAGase or SCC in milk samples from individual quarters. Figures 3 and 4 illustrate that milk from unhealthy quarters is diluted by milk from healthy quarters. Therefore, the concentrations of NAGase and SCC in composite milk are close to that measured in healthy quarters and thus, the identification of mastitic quarters is more difficult. However, Figures 3 and 4 indicate that, if NAGase or SCC has to be measured in composite milk, it would be advantageous to do that at the end of the milking, because the difference between healthy quarters and composite milk was greatest in that part of the milking. The difference in NAGase or SCC between healthy quarters and composite milk was larger when the cows were milked at a 6 -h than a 12 -h interval, indicating that a longer milking interval would make it more difficult to identify mastitic quarters on the basis of composite milk.

\section{DISCUSSION}

A wide variety of milk fractions [foremilk, cisternal milk, midmilk, bucket milk, post-strippings, residual milk, and young milk (see definition of young milk in Urech et al., 1999)] have been used to describe changes in milk constituents during and after milking. Typically, foremilk, main milk, and post-strippings have been used to evaluate what happens during a milking
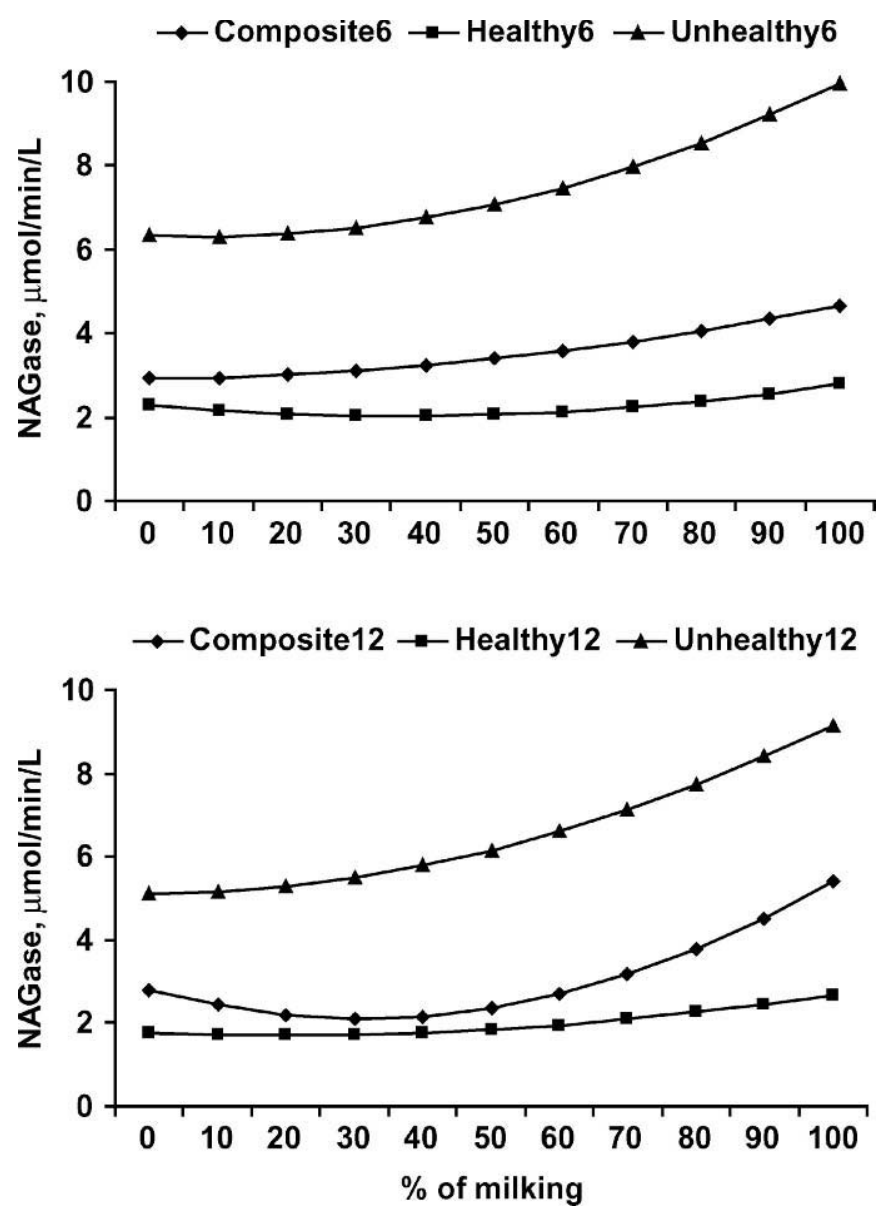

Figure 3. Mean concentrations of NAGase in healthy quarters ( $\mathrm{SE} \pm 0.49$ ), unhealthy quarters ( $\mathrm{SE} \pm 0.39$ ), and in composite milk ( $\mathrm{SE} \pm 0.50$ ) during milkings at 6 -h (top panel) or 12 -h (bottom panel) intervals. The concentration of NAGase in composite milk was calculated based on milk volumes and NAGase concentrations from each quarter sampling during milking.

(Holdaway et al., 1996; Godden et al., 2000) and sometimes, residual milk and young milk (Urech et al., 1999; Vangroenweghe et al., 2002) have been included to study what happens in the period just after milking. However, this study was conducted to establish how quarter health and milking interval affect the development of milk constituents during milking in relation to in-line sampling. Therefore, we were interested in the best possible description of milk constituents during the milking, and consequently chose to sample frequently. As milkings of individual cows cannot be expected to end at the same time within the milking interval, the end of milkings were standardized across cows and intervals by the use of a relative scale (\% of milking), as described in Materials and Methods.

This experiment included cows in different parities and lactation stages; that is, potentially fixed effects that could have been included in the statistical model. 

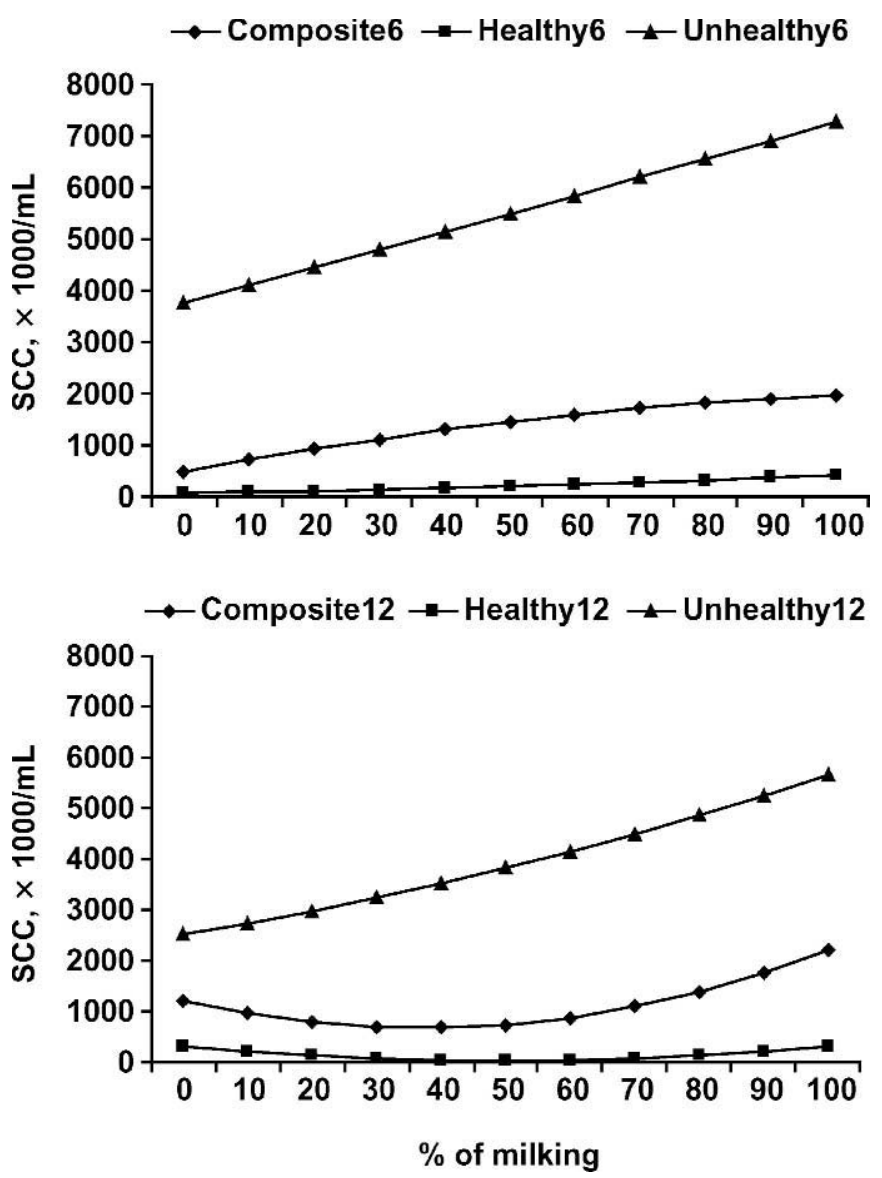

Figure 4. Mean concentrations of SCC in healthy quarters (SE \pm 379 ), unhealthy quarters ( $\mathrm{SE} \pm 648$ ), and in composite milk ( $\mathrm{SE} \pm$ 912) during milkings at 6-h (top panel) or 12-h (bottom panel) intervals. The concentration of SCC in composite milk was calculated based on milk volumes and SCC concentrations from each quarter sampling during milking.

Thus, an interaction between, for example, parity and milking interval might have been a possibility that cannot be excluded, but this was not investigated due to the limited number of observations in each subgroup. However, the strength of the experimental design is that all 11 cows were milked on both intervals and each cow had both healthy and unhealthy quarters; thus, each cow acted as its own control.

All milk constituents evaluated in this experiment were significantly influenced by quarter health, milking interval, and sampling time during milking, except for protein, which was not affected by milking interval. These effects are discussed below.

\section{Acetone}

Acetone is soluble in both hydrophobic and hydrophilic phases (Kaneko, 1989). Therefore, it was unexpected that acetone would be affected both by quarter health and milking interval. However, the quantitative effects were small, especially for quarter health (Table 2 ). We have no definite explanation of these effects. However, an increased $\mathrm{pH}$ in unhealthy quarters (Holdaway et al., 1996) could facilitate a reduction in acetoacetate being spontaneously converted to acetone (Bruss, 1997), thereby lowering the concentration of acetone in unhealthy quarters. In contrast to this study, Winterbach et al. (1993) found no relationship between acetone and either SCC or bacterial status in foremilk from individual quarters. There are several possible explanations for this discrepancy. First, Winterbach et al. (1993) used only foremilk, whereas we looked at the entire milking process. Second, Winterbach et al. (1993) did not use a factorial design with healthy and unhealthy quarters within cow, but made a regression analysis across cows. Finally, our study may have had a larger range in SCC compared with Winterbach et al. (1993).

The lower concentrations of acetone at the end of the milking resulted in relative differences from 12 to $17 \%$ between the lowest and the highest value of acetone within combinations of quarter health and intervals (Table 2). The decrease in acetone during milking was especially pronounced in cows with higher levels of acetone. Masson et al. (2004) measured higher concentrations of acetone in the middle of a milking compared with the beginning and end of a milking process, which is similar to when cows were milked at the 12 -h interval in our study. If acetone were to be used as an in-line indicator of ketosis, these results indicate that acetone is robust to the effects of quarter health, milking interval, and time in milking. The content of acetone was the same in foremilk $\left[-0.51\left(\log _{10} \mathrm{~m} M\right)\right]$ and milk collected throughout the milking process $\left[-0.51\left(\log _{10} \mathrm{~m} M\right)\right]$ in healthy quarters at the 6-h milking interval (Table 3 ). Further, Table 3 shows that there were no significant differences between the acetone content measured in foremilk and the acetone content measured in a sample collected throughout the milking; thus, a representative concentration of acetone can be obtained from the foremilk regardless of quarter health and milking interval.

\section{BHBA}

Like acetone, BHBA was affected by quarter health, milking interval, and sampling time during milking, but unlike acetone, these factors had a pronounced influence on the concentration of BHBA (Table 2). We found no literature with which to compare these results. The significantly higher BHBA concentration in unhealthy quarters during the whole milking process at both milking intervals may be due to loss of integrity of the tight junctions and thereby a leaky epithelium 
caused by a mammary infection (Stelwagen et al., 1997, 1999). Thus, the leaky epithelium results in a higher BHBA content in milk due to the much higher concentration of BHBA in blood (Nielsen et al., 2003).

The concentration of BHBA was lower when the cows were milked at a 12 -h compared with a 6 -h interval, at least in the first part of the milking. Thus, the development of BHBA during milking at different intervals suggests that BHBA more or less follows the fat fraction (Figure 1). This could be related to the hydrophobic properties of BHBA because BHBA is soluble in the hydrophobic compound ether (Anonymous, 1989).

The foremilk of unhealthy quarters had a BHBA content of 0.20 and $0.17 \mathrm{mM}$ (geometric means) for 6- and 12-h milking intervals, respectively. This level of BHBA in the foremilk was remarkably high compared with the first sampling during milking where it had dropped to 0.13 and $0.09 \mathrm{mM}$ (least square means) for 6- and 12-h milking intervals, respectively. This is also shown in Table 3 where the content of BHBA in foremilk is higher compared with milk from the rest of the milking at both milking intervals [ -0.68 vs. -0.88 and -0.79 vs. $\left.-0.91\left(\log _{10} \mathrm{~m} M\right)\right]$, although only statistically significant at the 6-h interval. Further, BHBA was significantly lower in foremilk [-1.13 $\left.\left(\log _{10} \mathrm{~m} M\right)\right]$ than in rest milk $\left[-1.03\left(\log _{10} \mathrm{~m} M\right)\right]$ in healthy quarters at the 12 -h milking interval. This indicates that foremilk is not always a suitable fraction for obtaining a representative value of the cow's ketotic status when using BHBA. The high content of BHBA in foremilk is most likely related to the high content of SCC/NAGase, which is consistent with the fact that BHBA was higher in unhealthy than in healthy quarters during the whole milking process.

Compared with the other indicator of ketosis (acetone), BHBA was more affected by quarter health, milking interval, and sampling time during milking (Table 2 ). Therefore, if BHBA were to be used as an in-line indicator of ketosis, a sampling procedure should be established that considers these effects. A representative sample should be obtained from healthy quarters and comprise the whole milking process. To accommodate for the effect of milking interval, BHBA values could be corrected for differences in milking interval in herds where milking interval differs in length.

\section{NAGase and SCC}

Several studies have shown higher levels of NAGase and SCC in foremilk, main milk, and post-strippings from infected quarters (Holdaway et al., 1996; Woolford et al., 1998; Urech et al., 1999). A high content of NAGase and SCC in foremilk, a lower concentration in midmilk, and a high content in post-strippings have been reported for both healthy and infected quarters
(Woolford et al., 1998; Urech et al., 1999), and this finding is in agreement with the present study (Figure 1). However, in noninfected quarters with $\mathrm{SCC}<85,000$ cells $/ \mathrm{mL}$, a higher content of NAGase and SCC in foremilk compared with main milk is not always evident (Berning et al., 1987; Holdaway et al., 1996; Vangroenweghe et al., 2002).

The 6-h milking interval led to higher concentrations of NAGase and SCC during most of the milking process (Figure 1), which is in accordance with previous findings where composite (metered) and bucket milk had a higher content of NAGase and SCC when cows were milked at an 8-h compared with a 16-h interval (Marschke et al., 1987; Kaartinen et al., 1990). Our study did not include repeated days within intervals, but practicing 8- to 16 -h milking intervals for $4 \mathrm{~d}$ also led to higher concentrations of NAGase and SCC at the shorter milking interval (Marschke et al., 1987). However, Weiss et al. (2002) used proportional sampling and did not find any difference in SCC when cows were milked with 4-, 8-, and 12-h intervals. An explanation of the high SCC at short milking intervals and the increase during the milking process could be that the release of somatic cells follows the ejection of fat globules from the alveolar cells. Thus, macrophages, granulocytes, monocytes, and lymphocytes, which comprise the somatic cells (Östensson et al., 1988), may have hydrophobic properties and therefore follow the fat in milk. Much of the NAGase arises from somatic cells (Kaartinen et al., 1990), which is probably the reason for the close linkage between SCC and NAGase. The high SCC in foremilk in both healthy and unhealthy quarters seems logical, as the bacteria have to enter the udder through the teat canal. In infected quarters, the high levels of SCC and NAGase in foremilk could also be caused by an infection within the teat sinus, gland cistern, or large ductal regions (Woolford et al., 1998).

The content of NAGase and SCC was higher in foremilk compared with milk from the rest of the milking, except in healthy quarters at the 12-h milking interval (Table 3). Therefore, using foremilk gives higher absolute levels of mastitis indicators compared with representative sampling throughout the milking. However, this does not preclude the use of foremilk to distinguish healthy from unhealthy quarters because the difference in NAGase and SCC between healthy and unhealthy quarters is still obvious in foremilk (Table 3 and Figure 1).

As shown in Figures 3 and 4, samples to identify udder health should be collected at quarter level and should comprise the entire milking process to accommodate for the effect of changes during milking. The diluting effect of healthy quarters on the content of NAGase 
and SCC in composite samples has also been demonstrated and quantified by Schaar and Funke (1986). This massive diluting effect is unwanted in a situation where NAGase or SCC is to be used as an in-line indicator because it is of interest to detect mastitis as early as possible after infection. Therefore, mastitis indicators should be sampled on quarter level.

\section{Urea}

Comparing urea in fat-free milk (Figure 2) and whole milk (Figure 1) shows that the difference in urea between healthy and unhealthy quarters was reduced in fat-free milk. This suggests that the more pronounced increase in fat for healthy quarters compared with unhealthy quarters toward the end of the milking is actually partly responsible for the significant effect of quarter health. Hoffmann and Steinhöfel (1990) did not find any effect of udder health on urea, probably because they compared mastitic and nonmastitic cows; that is, they compared at udder, not quarter, level. Furthermore, Hoffmann and Steinhöfel (1990) did not sample throughout milking, and thus could not detect differences in a specific part of the milking.

The effect of milking interval on urea was significant during the whole milking process, in contrast to acetone, BHBA, NAGase, SCC, fat, and lactose, where the effect of interval depended upon sampling time during milking. The higher content of fat when the cows were milked at a 6 -h compared with a 12 -h interval could not explain the effect of interval on urea (Figure 2). The effect of milking interval could also relate to feeding time relative to milking. Cows were fed at 1600 and $900 \mathrm{~h}$ and milked at 12 - and 6-h intervals beginning at 0500 and $1100 \mathrm{~h}$, respectively, meaning that they had been fed either 13 or $2 \mathrm{~h}$ earlier. If feeding provoked a higher urea level in the blood, it could have increased milk urea when the cows were milked at the 6 -h interval. However, the cows had free access to the TMR at all hours to minimize the effect of feeding. Feeding concentrates and roughages separately and limiting the amount of time that the cows had access to this feed have shown to increase milk urea after the morning feeding but not after the afternoon feeding (Miettinen and Juvonen, 1990; Carlsson and Bergström, 1994). However, there was no consistent diurnal pattern in milk urea in relation to 2 or 4 daily feedings of a TMR fed ad libitum at all hours to early lactating cows (N. I. Nielsen, unpublished data, 2003). Therefore, it is likely that urea is affected by milking interval, but it cannot be ruled out that time of feeding relative to milk sampling has contributed to the effect of milking interval in this study.
A reduced urea content in post-strippings has been reported in previous studies (Carlsson and Bergström, 1994; Godden et al., 2000; Jenkins et al., 2002) and can be explained by the increasing fat content as the milking process proceeds (Carlsson and Bergström, 1994). This was also true in our study, except for healthy quarters at the 6 -h milking interval, where the increase in fat was only partly able to explain the decrease in urea toward the end of the milking (Figure 2 ). Table 3 shows that at the 12 -h milking interval there was a higher content of urea in foremilk compared with milk from the rest of the milking for healthy quarters and no difference in unhealthy quarters. This is in contrast to Godden et al. (2000), who measured markedly lower urea contents in foremilk $(3.37 \mathrm{mM})$ compared with composite (metered) milk $(4.14 \mathrm{mM})$ in cows sampled in the morning (and therefore assumed to have been milked with approximately 12 -h intervals). This discrepancy could be explained by differences in methods for analyzing urea-Godden et al. (2000) used an infrared technology (Fossomatic 4000), whereas this study used a chemical method. Infrared technology has the disadvantage of relying on calibrations where other constituents such as SCC, lactose, protein, and fat influence the final urea result (Godden et al., 2000). As these constituents are greatly influenced in foremilk (Figure 1), they could fall outside the calibrations used by the Fossomatic 4000 and thus affect the urea results in foremilk (and post-strippings) in the study by Godden et al. (2000). In the present study, we measured urea both via a chemical method and on a CombiFoss 4000 . Comparison of these 2 urea datasets clearly showed that using infrared technology underestimates the urea content dramatically in milk with high SCC compared with a chemical method (data not shown).

If urea were to be used as an in-line indicator of protein status, our results indicate that urea is robust to the effects of quarter health, milking interval, and time in milking. However, the most representative sample would be obtained from healthy quarters, either in the beginning of the milking or comprising the entire milking process.

\section{Fat}

The significantly higher fat content in healthy compared with unhealthy quarters during the last half of the milking process has also been observed by Holdaway et al. (1996), who reported a much higher increase in fat content from foremilk to post-strippings in noninfected (3.70 to 10.74\%) compared with infected quarters (4.15 to 5.63\%). In agreement with the $100 \%$ fraction in the present study, Laitinen (1986) observed a tendency toward lower fat content in unhealthy quarters in post- 
strippings. We speculate that the reason for the lower fat content in unhealthy quarters during the last half of the milking process could be caused by damage of secretory epithelial cells due to infections. Such damage may impair milk fat synthesis leading to a lower fat content at the end of the milking. An experiment with goats indicated that the fat content is lowered when the concentration of $\mathrm{Na}$ is increased by intramammary infusion (Stelwagen et al., 1999). Because $\mathrm{Na}$ is elevated in infected quarters and especially in the last part of a milking (Bruckmaier et al., 2004), it might explain why the milk fat content is decreased in unhealthy quarters compared with healthy quarters during the last part of a milking process.

The significantly higher fat content at the 6-h compared with the 12-h milking interval during the first half of the milking is probably related to the way oxytocin provokes active transport of high-fat alveolar milk. Thus, the high-fat alveolar milk ejected at the end of the 12-h milking interval was not totally transferred along the mammary ducts before the milking ended (Lollivier et al., 2002). Therefore, when the cows were milked $6 \mathrm{~h}$ later, this high-fat alveolar milk was readily available in the foremilk as well as in the beginning of the milking. Weiss et al. (2002) also reported higher milk fat levels with decreasing milking interval. An increase in fat during the milking process has been reported in several studies (Godden et al., 2000; Lollivier et al., 2002; Masson et al., 2004).

If fat were to be used in an in-line system evaluating responses to feed management, a sampling procedure taking the effects of quarter health, milking interval, and sampling time during milking into account should be established. Surprisingly, there was no difference in fat content between foremilk and milk from the rest of the milking in unhealthy quarters (Table 3). This was the case at both milking intervals. In contrast, there was a major difference in fat content between foremilk and milk from the rest of the milking in healthy quarters. Thus, as expected, foremilk from healthy quarters cannot be used to assess the true milk fat level. A representative sample could be obtained from healthy quarters and should comprise the whole milking process. In herds where milking intervals differ, fat values should be corrected for the effect of milking interval.

\section{Protein}

The significantly higher protein content in unhealthy compared with healthy quarters during the whole milking process at both milking intervals has not been reported previously. Several studies have reported a tendency toward higher protein content in unhealthy quarters (Laitinen, 1986; Urech et al., 1999; Bruckmaier et al., 2004). We have no explanation for the higher protein content in unhealthy quarters, but it could be related to a reduced milk yield of unhealthy quarters or potentially the infrared technology used to measure protein, as discussed for urea. Weiss et al. (2002) found no effect of milking interval on milk protein, which is in agreement with the results from this study.

The decreasing content of protein in healthy quarters during milking is in accordance with other studies where the protein content in post-strippings was lower compared with foremilk (Carlsson and Bergström, 1994; Godden et al., 2000; Vangroenweghe et al., 2002) or bucket milk (Urech et al., 1999). Carlsson and Bergström (1994) reported that the reduction in protein from foremilk to post-strippings was eliminated when the protein content was calculated in the water phase of the milk. However, this was not the case in the present study (Figure 2), or in the study by Urech et al. (1999). Foremilk does not provide a representative concentration of protein compared with the protein content in milk from the rest of the milking (Table 3). A representative sample could be obtained from healthy quarters and should comprise the whole milking process. Alternatively, it could be obtained from all quarters during the first half of the milking where the effect of quarter health was insignificant.

\section{Lactose}

The significant effect of quarter health on lactose during the whole milking is in agreement with findings of Holdaway et al. (1996), who reported lactose to be significantly lower in infected compared with noninfected quarters in foremilk, midmilk, and post-strippings. Urech et al. (1999) did not find an effect of quarter health on the content of lactose, but this was probably due to the smaller difference in SCC between healthy and unhealthy quarters in their study. Explanations of the lower content of lactose in unhealthy quarters could be that bacteria consume lactose, lactose was measured using infrared technology, which may cause biased measurements (see urea discussion), or due to an elevated content of $\mathrm{Na}$, as discussed for fat (Stelwagen et al., 1999).

Weiss et al. (2002) found no effect of milking interval on milk lactose, in contrast to our study, where we observed higher lactose content at the 12-h interval in the first part of the milking process. However, the quantitative effect of milking interval was limited in our study (Table 2) and the reason why Weiss et al. (2002) did not find an effect of milking interval was probably that they used a proportional milk sample per milking. 
Irrespective of quarter health, lactose decreased during milking, which is in accordance with previous studies where the lactose content in post-strippings was lower than in foremilk (Carlsson and Bergström, 1994; Holdaway et al., 1996; Urech et al., 1999; Vangroenweghe et al., 2002). Carlsson and Bergström (1994) reported that the decrease in lactose from foremilk to post-strippings was eliminated when the lactose content was calculated in the water phase of the milk. However, this was not entirely the case in the present study (Figure 2), or in the study by Urech et al. (1999). Especially noteworthy is the parallel decrease in protein and lactose during milking, which suggests that mechanisms responsible for the transport of protein and lactose out of alveolar cells could be involved (Urech et al., 1999).

The lactose content in foremilk was remarkably lower than that in milk from the rest of the milking, except in healthy quarters milked at the 12-h interval. Therefore, foremilk is generally not suitable for obtaining a representative content of lactose, except in healthy quarters milked at the 12-h interval. A representative sample should be obtained from healthy quarters and comprise the whole milking process. Alternatively, it could be obtained as a composite sample because the effect of quarter health was limited.

\section{CONCLUSIONS}

All 8 milk constituents (acetone, BHBA, NAGase, SCC, urea, fat, protein, and lactose) measured in this experiment were significantly influenced by quarter health, milking interval, and sampling time during milking, except for protein, which was not affected by milking interval. Quantitatively, BHBA, NAGase, SCC, and fat were most affected by quarter health, milking interval, and sampling time during milking. Foremilk was remarkably different for all constituents, except acetone, and should not be used as a representative milk sample to achieve the true level of a milk constituent. If these milk constituents are to be used in an inline management system, these effects are of importance and should be taken into account.

\section{ACKNOWLEDGMENTS}

The authors wish to acknowledge the participation of Erik Frimer in the construction of milk machinery and his help with milk sampling. Further, we wish to thank Nic Friggens, Morten Dam Rasmussen, and Karen Helle Sloth for valuable comments and discussions in relation to the preparation of this manuscript. Dorte Agnholt, Dorte Thomassen, Carsten Berthelsen, and Jens Balslev Clausen are thanked for their analy- ses of milk samples, and Karin Østergaard for her assistance in preparing the manuscript. This study was financially supported by the Directorate for Food, Fisheries and Agri Business, Lattec I/S, the Danish Cattle Association, and the Danish Institute of Agricultural Sciences.

\section{REFERENCES}

Andersson, L. 1984. Concentrations of blood and milk ketone bodies, blood isopropanol and plasma glucose in dairy cows in relation to the degree of hyperketonaemia and clinical signs. Zbl. Vet. Med. A. 31:683-693.

Anonymous. 1989. Page 4743 in The Merck Index. S. Budavari, ed. Merck and Co., Inc. Rathway, NJ.

Berning, L. M., M. J. Paape, R. H. Miller, and R. A. LeDane. 1987. Variation in N-acetyl- $\beta$-D-glucosaminidase activity and somatic cell count among various milk fractions. J. Dairy Sci. 70:10541060.

Bruckmaier, R. M., C. E. Ontsouka, and J. W. Blum. 2004. Fractionized milk composition in dairy cows with subclinical mastitis. Vet. Med. Czech. 49:283-290.

Bruss, M. L. 1997. Lipids and ketones. Pages 101-143 in Clinical Biochemistry of Domestic Animals. J. J. Kaneko, ed. Academic Press, San Diego, CA.

Carlsson, J., and J. Bergström. 1994. The diurnal variation of urea in cow's milk and how milk fat content, storage and preservation affects analysis by a flow injection technique. Acta Vet. Scand. 35:67-77.

Friggens, N. C., and M. D. Rasmussen. 2001. Milk quality assessment in automatic milking systems. Accounting for the effects of variable intervals between milkings on milk composition. Livest. Prod. Sci. 73:45-54.

Godden, S. M., K. D. Lissemore, D. F. Kelton, J. H. Lumsden, K. E. Leslie, and J. S. Walton. 2000. Analytic validation of an infrared milk urea assay and effects of sample acquisition factors on milk urea results. J. Dairy Sci. 83:435-442.

Hamann, J., and V. Krömker. 1997. Potential of specific milk composition variables for cow health management. Livest. Prod. Sci. 48:201-208.

Heuer, C., Y. H. Schukken, and P. Dobbelaar. 1999. Postpartum body condition scores and results from the first test day milk as predictors of disease, fertility, yield, and culling in commercial dairy herds. J. Dairy Sci. 82:295-304.

Hoffmann, M., and O. Steinhöfel. 1990. Möglichkeiten und grenzen zur einschätzung der energie- und proteinversorgung durch kontrolle des milchharnstoffgehaltes. Mh. Vet. Med. 45:223-227.

Hogeveen, H., W. Ouweltjes, C. J. A. M. de Koning, and K. Stelwagen. 2001. Milking interval, milk production and milk flow-rate in an automatic milking system. Livest. Prod. Sci. 72:157-167.

Holdaway, R. J., C. W. Holmes, and I. J. Steffert. 1996. A comparison of indirect methods for diagnosis of subclinical intramammary infection in lactating dairy cows. 1 . The effects of bacterial infection, stage of lactation and age of cow on eight parameters in foremilk from individual quarters, with an initial study of differences between milk fractions. Aust. J. Dairy Technol. 51:64-71.

Horber, H., F. Mäder, and H. Jucker. 1980. Ketonkörperkonzentration in blut, milch und urin bei gesunden und an primärer ketose erkrankten milchkühen. Schweiz. Arch. Tierh. 122:553-564.

Jenkins, D. M., M. J. Delwiche, E. J. DePeters, and R. H. BonDurant. 2002. Factors affecting the application of on-line milk urea sensing. Trans. ASAE 45:1687-1695.

Kaartinen, L., T. Ali-Vehmas, and M. Sandholm. 1990. Effect of frequent milkings on milk NAGase, plasmin, trypsin inhibitory capacity and the quality of whey as the growth medium for mastitis pathogens. J. Vet. Med. B. 37:337-344.

Kaneko, J. J. 1989. Carbohydrate metabolism and its diseases. Pages 44-85 in Clinical Biochemistry of Domestic Animals. J. J. Kaneko, ed. Academic Press, San Diego, CA. 
Kitchen, B. J., G. Middleton, and L. Salmon. 1978. Bovine milk Nacetyl- $\beta$-D-glucosaminidase and its significance in the detection of abnormal udder secretions. J. Dairy Res. 45:15-20.

Laitinen, J. T. 1986. Level and distribution of progesterone in bovine milk: Effects of mastitis and milk composition. Br. Vet. J. 142:562-568.

Larsen, T., and N. I. Nielsen. 2005. Fluorometric determination of $\beta$-hydroxybutyrate in milk and blood plasma. J. Dairy Sci. 88:2004-2009.

Lollivier, V., J. Guinard-Flament, M. Ollivier-Bousquet, and P. Marnet. 2002. Oxytocin and milk removal: Two important sources of variation in milk production and milk quality during and between milkings. Reprod. Nutr. Dev. 42:173-186.

Marschke, R. J., R. Roberts, and B. J. Kitchen. 1987. The effect of sampling time on $\mathrm{N}$-acetyl- $\beta$-D-glucosaminidase (NAGase) levels in bovine milk and its relevance to mastitis diagnosis. Aust. J. Dairy Technol. 42:3-10.

Masson, L. L., T. T. Mottram, and P. C. Garnsworthy. 2004. Within milking variation of urea, acetone, fat and protein and determination of sampling time for an on-line system. Online. Available http://www.sri.bbsrc.ac.uk/images/posters/cowonline.pdf. Accessed Oct. 29, 2004.

Miettinen, P. V. A., and R. O. Juvonen. 1990. Diurnal variations of serum and milk urea levels in dairy cows. Acta Agric. Scand. 40:289-296.

Mottram, T., M. Velasco-Garcia, P. Berry, P. Richards, J. Ghesquiere, and L. Masson. 2002. Automatic on-line analysis of milk constituents (urea, ketones, enzymes and hormones) using biosensors. Comp. Clin. Pathol. 11:50-58.

Nielsen, N. I., N. C. Friggens, M. G. G. Chagunda, and K. L. Ingvartsen. 2005. Predicting risk of ketosis in dairy cows using in-line measurements of beta-hydroxybutyrate: A biological model. J. Dairy Sci. 88:2441-2453.

Nielsen, N. I., K. L. Ingvartsen, and T. Larsen. 2003. Diurnal variation and the effect of feed restriction on plasma and milk metabolites in TMR-fed dairy cows. J. Vet. Med. A. 50:88-97.

Ontsouka, C. E., R. M. Bruckmaier, and J. W. Blum. 2003. Fractionized milk composition during removal of colostrum and mature milk. J. Dairy Sci. 86:2005-2011.

Östensson, K., M. Hageltorn, and G. Åström. 1988. Differential cell counting in fraction-collected milk from dairy cows. Acta Vet. Scand. 29:493-500.
Pyörälä, S. 1988. Indicators of inflammation to evaluate the recovery from acute bovine mastitis. Res. Vet. Sci. 45:166-169.

Rajala-Schultz, P. J., and J. A. Saville. 2003. Sources of variation in milk urea nitrogen in Ohio dairy herds. J. Dairy Sci. 86:16531661.

SAS Institute. 1999. SAS OnlineDoc, Version 8. SAS Institute Inc., Cary, NC.

Schaar, J., and H. Funke. 1986. Effect of subclinical mastitis on milk plasminogen and plasmin compared with that on sodium, antitrypsin and N-acetyl- $\beta$-D-glucosaminidase. J. Dairy Res. 53:515-528.

Schüttel, M. 1999. Vergleich von N-acetyl- $\beta$-D-glycosamidase-Aktivitäten (NAGase) in Milch, Blut und Harn beim laktierenden Rind. Ph.D. Diss. Tierärtslicher Hochschule, Hannover, Germany.

Steen, A., O. Østerås, and H. Grønstøl. 1996. Evaluation of additional acetone and urea analyses, and of the fat-lactose-quotient in cow milk samples in the herd recording system in Norway. J. Vet. Med. A. 43:181-191.

Stelwagen, K., V. C. Farr, and H. A. McFadden. 1999. Alteration of the sodium to potassium ratio in milk and the effect on milk secretion in goats. J. Dairy Sci. 82:52-59.

Stelwagen, K., V. C. Farr, H. A. McFadden, C. G. Prosser, and S. R. Davis. 1997. Time course of milk accumulation induced opening of mammary tight junctions and blood clearance of milk components. Am. J. Physiol. 273:379-386.

Urech, E., Z. Puhan, and M. Schällibaum. 1999. Changes in milk protein fraction as affected by subclinical mastitis. J. Dairy Sci. 82:2402-2411.

Vangroenweghe, F., H. Dosogne, and C. Burvenich. 2002. Composition and milk cell characteristics in quarter milk fractions of dairy cows with low cell count. Vet. J. 164:254-260.

Weiss, D., M. Hilger, H. H. D. Meyer, and R. M. Bruckmaier. 2002. Variable milking intervals and milk composition. Milchwissenschaft 57:246-249.

Winterbach, H. E. K., P. J. Apps, W. Giesecke, and I. Petzer. 1993. Cyclic fluctuations in acetone concentrations in the blood and milk of clinically healthy dairy cows. Onderstepoort J. Vet. 60:247-255.

Wittkowski, G., W. Gedek, and E. Kleinschroth. 1979. Mastitisdiagnostisch wichtige messwerte von fraktioniert gewonnenen milchproben vom rind. Arch. Lebensmittelhyg. 30:19-22.

Woolford, M. W., J. H. Williamson, and H. V. Henderson. 1998. Changes in electrical conductivity and somatic cell count between milk fractions from quarters subclinically infected with particular mastitis pathogens. J. Dairy Res. 65:187-198. 